\title{
Victim's Right of Access to International Criminal Courts
}

\author{
Fazlollah Foroughi ${ }^{1} \&$ Zahra Dastan ${ }^{2}$ \\ ${ }^{1}$ School of Law and Political Science, Shiraz University, Shiraz, Iran \\ ${ }^{2}$ Shiraz University, Shiraz, Iran \\ Correspondence: Fazlollah Foroughi, School of Law and Political Science, Shiraz University, Shiraz, Iran.
}

Received: September 4, 2016 Accepted: October 2, 2016 Online Published: December 29, 2016

doi:10.5539/jpl.v10n1p279

URL: http://dx.doi.org/10.5539/jpl.v10n1p279

\begin{abstract}
Due to quantitative expansion and evolution in committing the crime at the international level, the scope of criminal proceedings has been widened significantly. Tolerance and forgiveness towards crimes that happen at international level not only is a double oppression on the victims, but also provide a fertile context for others to commit crimes more daringly. Thus, it is essential that international criminals are held accountable to the law and competent institution, and the realization of this issue leads to the victim satisfaction in international law. Not only in international law, but also in domestic law, show respect and protection of human rights is effective only when there is an effective justice system to guarantee the rights. Although some international crimes practically occur by the government or at least high-ranking government officials, the Statute of the International Criminal Court has reiterated this point that they only have jurisdiction over the crimes committed by natural persons rather than legal entities, which one good example is governments, and although the real victims of these crimes have been human beings, in the case of action and referring the case to the competent international courts, these are the states (rather than the victims) that actually have the right of access to the authorities and not beneficiaries. Thus, at the first step, we should see whether the Court has jurisdiction over the crime committed by the government and whether people can file an action independently in the International Criminal Court or not? When people, rather than governments, are beneficiaries in some international crimes, why only the government and not the people is the plaintiff? And what is the right of the victim in such category of crimes? Accordingly, the current research seeks to examine these rights and restrictions, and relevant limitations.
\end{abstract}

Keywords: victim, criminal justice system, international courts, damage compensation

\section{Introduction}

A review of criminology and criminal Justice suggests that the research performed by criminologists and criminal law issues focuses more on some elements such as crime, offenders and punishment, then the victim and crime have been overlooked, and have lost their significance in various stages of the criminal justice. In contrast, protection of rulers and governments has been underlined. While the victim is an important element in criminal process, unfortunately, he has not achieved a high status in the body of research relevant to criminology, and the necessity to advocate this critical element depends on providing global, regional and local strategies to enable the victim to achieve its lost rights. Although the Victim's Rights Movement is still in its infancy, it has been able to achieve a great status in a short time and to attract the attention of the global community. The idea of victim protection enacted into objective law after World War II under different titles such as demanding the right to losses in the criminal case, fair trial, and victim compensation. The actions taken by some scientists such as Van Bemmeilen \& Margery fry and then the Charter on the Rights of Victims of Criminal Acts by Andre Normanadeau have played significant roles in Victim's Rights Movement, and has motivated the founders of the social defense school under the leadership of Mark Ansel to strengthen, sustain and enrich their plan to support the victim (Pradle, 1991, pp. 142 and 144). Even according to domestic law, crime both has public and private aspect, and in addition to its impact on public disorder and endangering social benefits compared to private aspect, it underlines also private aspect. Private aspect is a person's right to claim for the damages caused by the crime and his right to refer to the court and demand for the punishment of the accused, and also focuses on individual materials in addition to social interests. Thus, the pertinent right must be considered more emphatically in relation to international crimes (Foroughi, 2004, p. 18). The necessity of protecting the victims and a wide range and value of this new idea and solid base forced international organizations to ratify the plan in the protection of victims of international crimes in international conventions and documents. In relation to the 
victim or the injured party, three issues must be taken into account. Firstly, whether or not the rights of the injured party can be compensated? Second, whether or not the injured party or his representative can be present in the proceedings or not? Thirdly, whether or not the injured party itself or his representative can be the initiator of action to begin proceedings in the court?

What can be seen about the victims of international crimes is that the victims are finally asked to testify in court about what happened, while the victims of such anti-human war crimes are not merely the witnesses to these crimes, and they are the damaged parties of the crimes, and in addition to support, they are deserved to be advocated whether in the time of investigation or within the context of a criminal procedure, and the victims should not merely play a passive role as the persons under the protection, but victims demand these rights as one party of action, and they demand the right of expression versus the International Criminal Court.

Inherent jurisdiction of most international courts is in addressing the crimes of natural individuals, yet the rights of the victim in filing a complaint as a victim of international crimes have not directly expressed. However, fair hearing requires alignment between the rights of victims and suspects and, the victim' possibility to the criminal justice system can ensure the dignity of a man to make an attempt to restitute its lost rights due to violations. In addition, fair treatment of the victims and victim's right to access in a criminal justice depends on predictable legal mechanisms to protect the victims. The principle of access to justice is one of the guiding principles in the general theory of civil procedure that has a moral and practical basis, and one of the features of the principle of access to justice is free and fast access and the allocation of resources and legal facilities to injured parties and victims of crime, which unfortunately, the lack of attention to the rights of the victims has led to the retreat of the state from its extremist policies, the abandonment of victims in criminal trials and, ultimately, compensation. Notably, due to the fact that "Offenses against the government" is still the headline of most of criminal codes, the dominant trend still revolves around the decline of victims' legal position and pay regard to the government's interests and protection of them.

Article 14 of the International Covenant on Civil and Political Rights supports the right to a fair trial in an independent and impartial court, and underlines legal protection of individuals against being deprived of the fundamental rights. Thus, the right to access to international courts in the criminal justice system should be one of the principles of fair justice to the victims of international crimes. This is an issue that is addressed in the current research and is the fulcrum of this article: the victims and their role in litigation and compensation. Thus, the victim is driven from the margins to the text and the question arises whether victims of violations of international law can take the privilege of justice and compensation or not?

In the meantime, we should identify the failures of international criminal law with regard to victims and recognize the strategies for getting access to victims during an international appeal directly as the complainant of these crimes, and explicitly, seek to find an answer to the question that whether the victim's right to access to International Criminal Court, individually and not by the government on behalf of victims of international crimes, has been accepted or not? And whether the role of the victim in the criminal justice process at the international level is subject to the total direct compensation from it or its right to file an action in international courts? The current article first analyzes the approach adopted by the international community with respect to the rights of victims of international crimes, and in this regard, the article examines the conventions and declarations on the rights of victims to make compensation for losses. And after reviewing the regulations governing fair trial jurisprudence of the International Criminal Court, the victims of international crime are investigated.

\section{Approach Adopted by International Community to the Victim's Right of Access to the International Criminal Court}

The victim is an important element in the criminal process, which has suffered from losses and damages as a result of crime, and the necessity to protect him in terms of the development of crime depends on regional and universal and domestic strategies, and given the existing barriers to victims of crimes, especially at the international level to the criminal justice system, the protections provided must enable the victim to get access to the criminal justice system and restitute its lost rights. However, there are some obstacles in this regard that must be taken into account, and the highlighted role of the victim in the criminal process is considered as a result of the emergence and expansion of protective criminology (Tavajohi, 2002, p. 53).

Right means a person's special privilege to some of the things, thus legal protection is a prediction of some solutions for the rights of victims in a criminal process and the victim is the person who pursuant to the occurrence of a crime suffers from harm or damage in a psychological, physical, emotional, and financial form, or its fundamental rights can be injured (Raijian Asli, 2002). Then victimology is the study of victim and the occurrence of crime, and also the role of victim in the occurrence of the crime, and the extent of the damage 
inflicted on the victim and eventually an investigation of the status of victims in the criminal justice system. The importance of legal proceedings and access to justice and show justice to crime victims is an aspect for validating the proceedings, and judicial institutions as a source for service provision in a progressing environment can make significant contributions to the establishment of a balance between the two parties and to allocate judicial resources in accordance with the principle of equality of arms within the context of judicial structure with regard to both parties of an action.

Concerning what it means "victim", the Declaration of the United Nations General Assembly in 1985 defined the victims in international law: "The victims are persons who individually or collectively suffer from particular damage to their physical integrity or mental, physical loss, or damage to their basic rights as a result of acts or omissions arising out of violation of criminal laws.

What is important in this definition is the fact that direct victims of crime are the same natural beneficiaries who have suffered damage, thus the question is that: why when people are victims of international crimes, they have no place in the court and proceedings? In the courts, the only authority for instituting legal proceedings is a prosecutor, and it is unforeseen that victims can play a role in this process. However, recently, United Nations Commission on Human Rights passed a recommendation about the arrival of a group of victims in the proceedings in order to "present collective petitions for compensation and collective reparations"”. However Exclusive Tribunals Proceeding Bylaw does not foresee any possible intervention for victims in a role other than witnesses in court (valine, 2006, p. 39).

Establishment of the International Criminal Court to investigate crimes by the perpetrators of genocide, war crimes and crimes against humanity during World War II in the former Yugoslavia, Rwanda, Sierra Leone and finally the establishment of the International Criminal Court are the critical actions to execute justice and terminate irresponsibility and lack of punishment for the murders, and to prevent the repetition of these crimes and also to reestablish the power of law. However, according to some experts, the developments and catastrophes of the two world wars, progressed individual from the margins to the context of international law, and made him as a subject (though passive or incomplete) to the function of international law. These developments led to the proposition of new theories in this area and raise of serious questions about the status of the individual in international law, to the extent that some experts considered the individual as merely subject to international law, and some selected a middle way and placed the person along with other followers, and some others did not recognize any position for the individual in such legal system. This issue is important under the conditions when the person is an active subordinate to international law, including victims of grave breaches of international humanitarian law, thus is entitled to claim direct reference to the violator state and demand compensation. This means that it would be possible to extend compensation to the relationship between the individual and the state.

Human rights' law in relation to the rights and protection of victims and their compensation compared with the rules of international criminal law is much more advanced and have been evolved more quickly in the recent years. Many international and regional human right instruments have found a general legal framework for the right to compensation and to receive compensation for victims of human rights' violations, and they have also imposed some obligations and punishments on the violators of human rights.

\subsection{The European Convention on the Compensation of the Injuries Caused to Violent Crime Victims}

The first international document on the rights of victims of crime is explicitly "the European Convention on the compensation of violent crime victims" that was approved by the members as an initiative of the Council of Europe on November 24, 1983. This convention protects the victims of violent intentional crimes whose bodily integrity or health has been damaged, or the persons whose guardians have died as a result of crime.

\subsection{Declaration of Basic Principles of Justice for Victims of Crime and Victims of Abuse of Power}

At the global level, "Declaration of Basic Principles of Justice for Victims of Crime and Victims of Abuse of Power" as the subject of United Nations General Assembly Resolution of November 29, 1985 is the first document addressed to the Member States, and recommends the compensation for physical, spiritual, moral and emotional sufferings as crime victims' rights and the victims of abuse of authority, which contains 21 articles in line with the protection of the rights of victims and relieve their sufferings, and has committed the governments to comply with them. Thus, while introducing some special institutions, the Declaration wants the governments to evolve their penal rights in terms of easy access to the Judiciary, and to medical, psychological and social assistance to victims of crime (Kaptain and Malj, 2005). By defining the term "victims", the Declaration has announced the victims' rights, especially the right to petition. United Nations basic principles on the right to

${ }^{1}$ Commission des droit de l'homme.Doc.E/CN.4/2000/62. 
compensation and pay compensation to victims of serious human rights violations and international humanitarian law are other international instrument adopted by the General Assembly of the United Nations. This instrument underlines the importance of the petition issue and compensation for victims of serious human rights violations and international humanitarian law and international community's commitment to address the pain and suffering of the victims, survivors and future generations. In the light of international and global approaches, the Declaration presents the best evidence to advocate victims, both substantially with an emphasis on penal protections of the victims of crimes and formalistically in terms of the Code of Criminal Procedure in the criminal process in order to restore the rights of victims involved, and this means examining a fair process in support of the victim in the criminal justice system

\subsection{Recommendation on the Position of the Victim in the Framework of Criminal Law and Criminal Procedure}

Council of Europe in the form of Recommendation 28 June 1985 of The Committee of the Ministers entitled "The position of the victim in the framework of criminal law and criminal procedure" underlines further consideration of the criminal justice system to physical, psychological, social, material damages inflicted to victims at different stages of the criminal process. However, in none of these cases, the possibility of a direct lawsuit in international bodies is not discussed, and this is a big gap in the current state of victim rights in the criminal justice system.

\section{The Victim Access to Justice in Fair Proceedings in Line with International Instruments}

Justice is the ultimate goal of any legal proceeding and fair trial is one of the most important characteristics of social and judicial development of any society. The concept of a fair trial represents a trend in the United Nations criminal policy. This trend, based on international standards of human rights, considers disregard or violation of the rights of the offender or the victim within the criminal justice process as the manifest violation of human rights. Thus, with a victim-oriented insight, the relevant trend recognizes the victim or the same injured person as the victim of violations of human rights and fundamental freedoms.

Thus, any behavior that is indicative of the loss of fundamental freedom rights or disrespect and desecration of human dignity or personality and a breach of privacy is a clear violation of human rights and the injured party can be considered the victim of such behavior (Raijian Asli, 2005, p. 141). Assess the fairness of the proceedings is made possible only through the definition of criteria and norms as the minimum necessity for a fair judicial process. Principles of fair trial in the criminal investigation process are very important. For the administration of justice and the restitution of altered and violated order as a result of committed crime, criminal laws and rules must comply with two fundamental principles of "maintaining public order" and "observance of rights and freedoms" to accomplish a fair trial and to observe individual rights and freedoms at all stages of criminal proceedings. Then, the hearing is fair only when it can establish a balance between the interests of society and the defendant ${ }^{2}$ (Omidi, 2003, p. 132).

Then, a long criminal procedure is fair when it takes privilege of the principles and criteria which guarantee the rights of all parties involved in a conflict and criminal case including the defendant, victim, witnesses and informants. These principles are the procedures that determine the basic concepts of justice in settling disputes (Pourostad, 2006, p. 13). Universal Declaration of Human rights and the International Covenant on Civil and Political Rights are the most important international instruments on human rights adopted by many countries and including the Islamic Republic of Iran as well. These two documents contain the most fundamental rights of human beings, and consider different standards for fair trial to guarantee human rights, including the presumption of innocence, the principle of impartial justice authorities, and the principle of public trial (Shams, 2004, p. 154).

Human Rights in the framework of conventional and customary international rights include two sets of rights that are supportive of human dignity. First, positive rights that should be provided to all individuals, and second, negative rights, i.e. the behaviors that their commitment toward humanity, whether as victim or the accused, are prohibited, and prohibition of each of these rights causes that the person as the holder of the rights to be considered as a victim (Raijian Asli, 2001; pp. 76-80).

\footnotetext{
${ }^{2}$ To protect the individual petition right and to anticipate such right, Article 34 of the Constitution reinstates that: anyone has a legal right of recourse to the courts, and all citizens have the right to refer to competent courts. All nation have the right to get access to such courts, and no one can be barred from referring to the court. In addition, regarding the authorities' task to perform an independent and objective investigation and trial of people's proceedings as a guarantee to prevent from the violation of this issue, Article 570 of the penal code states that: each of officials and officers and organizations affiliated to institutions and state systems that deprive citizens of their individual freedom, or make them deprived of the rights enshrined on Iran's Constitution should be dismissed and suspended for one to five years of government jobs and also imprisonment from two months to three years.
} 
Given the brutal crimes committed in the World War, in order to get access to justice and fair treatment to the victim, the United Nations speaks of the human rights relevant to a victim. Thus, fair trial protects people of their rights and fundamental freedoms, and as the principles of fair hearing applies to prevent violation of fundamental human rights, they can also be used for justifying the human rights of victims. Accordingly, based on the principles, in accordance with the norms of international human rights law, to prevent the occurrence of violations of human rights and criminal prosecution of perpetrators of these crimes, and to punish the perpetrators of these violations, the implementation of these norms can be guaranteed.

One effective example in this regard is supportive patterns of the Declaration 1985 in line with access to justice and fair treatment to the victim. In this declaration, one of the criteria to benefit from fair treatment and access to justice is that, under paragraph 5 of this Declaration, victims shall be able to directly participate in the criminal justice process to restitute their lost rights. In this line, making victims informed of their facilities and awareness of their role in the litigation process is important. In addition, in accordance with paragraph 14 of the Declaration, appropriate assistance in the form of financial, medical, and social supports shall be provided to the victims for enabling them to get access to justice and litigation.

Furthermore, the victim should be protected of direct confrontation with the offender and his threats (right to guarantee security-paragraph 6 of the Declaration), and these cases have been considered in the principles and basic guidelines on the right to compensation and rehabilitation for victims of gross violations of human rights. Some of the main purposes underlying the Convention include notification, service provision, restitution and compensation, and victim participation in the criminal justice process in order to access to justice and fair treatment are.

\section{Victim's Right of Access to Courts on Criminal Justice}

In international law, same as civil rights, respect for and protection of human rights is effective and efficient if there would be effective legal trial systems in order to guarantee the rights of the victims of international crimes, and when these rights are violated, accessibility to the justice system is crucial for the injured individual, and this is the most fundamental element of the human right protection system.

Right to fail trial is the possibility of a lawsuit by a person before a court which the court can issue decrees and consider sentencing proceedings based on fair standards, and naturally, the relevant right shall include a person who seeks to file an action under the jurisdiction of a competent court.

The right to access to the courts has been anticipated in many international human right instruments, and one good example is Article 10 of the Universal Declaration of Human Rights, which states that: "Everyone is entitled to full and equal access to an impartial and independent hearing to be able to deal with any criminal charge against himself and to guarantee his rights and obligations.

In addition, in Article 14 of the International Covenant on Civil and Political Rights on the right to access of victims to the courts, he states that: "All are equal before the courts and the Court of Justice. Everyone has the right to a fair and public hearing within a competent, independent and impartial court established by law, and the relevant court should decide on the legitimacy of the criminal charges against him or disputes concerning the rights and obligations in a civil case.

The right to access to the court is one of the most important features of an effective criminal justice system. The relevant right is comprised of a set of legal and institutional components relevant to the criminal justice system to provide legal services. This principle was cited for the first time in 1975 by Strasbourg Court, and it indicates fair and equal access to the judicial system and possibility to carry out a prompt and reasonable litigation.

Justice has been an ideal goal for all ages in individual and social, national, transnational areas worldwide. Litigation is one of the most important rights of citizens to tolerate, resolve and terminate their hostilities. Therefore, all citizens shall have the right to justice and fair trial to be able to refer to competent, impartial and independent courts and to justify their right based on a fair process.

The Working Group on Quality of Justice (CEPEJ-GT-QUAL) of the European Commission for the efficacy of Justice, introduced access to the Judiciary as an introduction to access to justice. Andrew Neil in his paper entitled "The fundamental principles of civil procedure" regards the principle of access to justice hearing rights as an ethical principle underlying legal proceedings, and considers the paragraph 3 of Article 6 of the European Convention on Human Rights as the legal basis of this principle. In addition, Article 13 of the Convention on the right to effective remedy states that any person whose rights and their freedom is lost even if his rights and freedoms are violated by official authorities, he/she is entitled to the right to an effective remedy before a national authority in accordance with paragraph 3 of Article 6 of the minimum right of access to competent 
courts.

Facilitated access to justice and the Judiciary means the availability of legal services in general and the availability of judiciary services in a certain sense, and the ease of access to justice is subject to the fundamental safeguards, and equal conditions should be provided in the judicial process. International crime is a crime in which one of the parties is a government that commits crimes against humanity and violates individual rights and freedoms, yet the crimes are committed against individual members of a society, and these are people who have been victims of crime, and the ones who seek to restore their lost rights through an independent justice.

In every human society, justice and order compensation have been accepted as a general principle of law. As in the domestic systems, one of the tasks of the Judiciary is to address claims and restitute the lost rights of the parties. This right also is present in the international system, yet rule-based international humanitarian law is overshadowed by government's authority, and there are some gaps with regard to litigation toward an aggressive state in an international court apart from retaliated actions taken by the governments.

Different international courts have been formed to punish violators of international humanitarian law. However, in none of these developments that seek to prevent the impunity of offenders, victims have not played independent and significant parts. And the question arises whether the victims of crimes against humanity also have the right to appeal or not. In addition to the governments, "individual" is also a subject of international law and he shall be respected in the international legal system, and the issue is important due to the fact that individual as a subject of international law deserves to make a direct reference to the aggressor state and or the parties that are violators of human rights, and to order compensation from them, because the relationship between compensation due to violation of international humanitarian law is not merely the relationship between governments and can be extended to the individual and aggressor government as well. However, the right to access to court in the European Convention on Human Rights has not been mentioned explicitly, in Golder v. Case where The UK Interior Ministry detained a person from contacting his lawyer, the Court presented a broad interpretation of paragraph 1 of Article 6 of the European Convention on Human Rights, and issued 9 agreed votes in favor of granting the right to access to court both legally and thematically.

Violation of international law by a government can lead to an international liability, and the main challenge underlying public international law system is the implementation of the rules, which along with the judicial punishment of international law violators, the concept of compensation is raised. Undoubtedly, the victims themselves play a critical role in justifying their rights, and it is only through their efforts that it would be possible to take serious and positive steps to remedy them and receive compensation. Thus, within the framework of international law, the vacuum of identifying the right of victims of violations of international law in private litigation, in addition to the international responsibility, should be examined as an independent subject.

Strategies to support the victims are criminal or non-criminal means, tools and methods that are used for justifying the rights of the victim. At an international level, the strategies to support the victims at three levels including legislative, judicial and executive are studied, and in the legislative area, some documents such as the UN Convention Draft on the Judiciary and support for injured parties and victims of abuse of power, Statute of International Criminal Court and the European Convention on Compensation to Victims of Violent Crime. However, in practice, these documents are not sufficiently effective and have failed to provide sufficient support of the victim on the basis of the documents within administrative territory.

\section{History of the Jurisprudence of International Tribunals to Victims}

Crimes committed in the twentieth century resulted in the victimization of millions of people around the world. In addition, the attempts to adopt effective measures to prevent the recurrence of these crimes were a great concern to the international community.

The first international tribunal to investigate acts of civilians and military leaders of Nazi Germany after World War II and the defeat of Germany was the Nuremberg military tribunal that was formed on 20 November 1945 by the victorious nations and then was the Tokyo District Court. The necessity of forming the military courts in Nuremberg and Tokyo in the form of the phrase "international peace and security" was justified (Musila, 2009, p. 5). The primary objective of the formation of the courts was to impose penalties on criminals in violation of humanitarian law, and protect the interests of victims in the courts was a secondary matter.

In both courts, victims' protection gap was seen, and almost at both courts, no right was recognized for victims' involvement or participation in the hearing process, and the only issue under investigation and judgment was to punish the leaders of the countries concerned. Although the two courts had the duty to punish the perpetrators of crimes against humanity, they overlooked the implementation of restorative justice to victims of damages, and at 
the same time, they were not able to prevent the continuing violations of international humanitarian law, war crimes and crimes against humanity, and there was not a legal entity for litigation of these crimes, and the two Courts took action under their independence and discretion independently.

After these two courts, the war against Bosnian Muslims in the territory of the former Yugoslavia as the biggest battles of World War II led to the creation of the International Tribunal for the Former Yugoslavia in 1993 and then the Rwanda Tribunal in 1994 by the United Nations Security Council. The court activities not only led to the formation of the new concepts and development of international humanitarian law, but also accelerated the formation of the International Criminal Court.

In the preface to the resolution of international criminal tribunals for Yugoslavia and Rwanda in both courts, the victim is a person who has been suffered as a result of the commission of international crimes. In hearing process, despite the protection of the victims as witnesses, a very limited role was granted to the injured party in the criminal process, and the victims were deprived of the right to order compensation or participation in the court hearings, and the victims not based on their own will to file a complaint or pursue litigation but under the court's discretion could only appear as a witness in the court. Concerning the rights of victims in Rwanda litigation in the courts, this issue was felt as a legal vacuum by the victims and in particular the organizations as the protector of survivors and relatives of the genocide crimes in Rwanda, and the International Criminal Tribunal for Rwanda in turn identified this problem, and sought to allow representatives of some associations as helpers of victims to amend the shortages in the form of non-beneficiaries to enter the case.

Thus, the prosecutor office of these two courts was the only body with authority to start the prosecution of criminals (Zakerian, 2013, p. 216) and did not recognize any right to give direct access to them as victims of crime. In addition, this Court was formed to determine violations of human rights and humanitarian law, review and explain the crime, identify authorities and the perpetrators and their punishment, and finally pay compensation to victims. However, the provisions of both courts for guaranteeing payment of compensation to the victims were inadequate. Finally, based on the Articles (3) 24 of the Yugoslav Tribunal and Article (3) 23 of Rwanda Tribunal, the restitution of property to the rightful owners was anticipated, even though there were no regulations on direct appeal of victims with respect to property restitution or compensation for physical and psychological injuries of victims (Zakerian, 2002, p. 123). However, the procedures to the International Criminal Tribunal for Cambodia incorporate the set of rules that ensure respect for the victims to enable them to participate in the criminal process as a complainant or witness. This is because, according to the Statute of the Court of Cambodia, the victims as one of the parties can request the prosecutor to sue criminals, and have access to evidence presented to the court (Pradle, 2007, p. 23).

In addition, the Statute of the International Criminal Court (consolidated) of East Timor includes new regulations on the participation of victims in criminal procedure and protection of the victim and the victims of crimes against humanity can request some specific investigation from the prosecutor and even during the proceedings of the hearings, they can present comments or request the revision.

The International Criminal Tribunal for Lebanon as a temporary and case-oriented court was formed by the UN Security Council to prosecute the officials involved in the assassination of Rafik Hariri, Prime Minister of Lebanon in 200. Under the jurisdiction of the Court, more explicit than other international courts, the victims were allowed to participate in the court proceedings in accordance with Article 17 of the Statute of the Court entitled "The rights of victims of crime" and have the right to have a voice and even victims could personally or through their legal representatives refer to Lebanon or other competent authorities, and make a request for compensation and redress (Aqaei Jannat Makan, 2009, p. 40).

International Criminal Court (ICC) that was formed based on an agreement with a number of countries and to prosecute and punish perpetrators of serious international crimes under the Rome Conference in 1998, is a new step in this direction. One of the major issues in the Court's Statute and Rules of Procedure and relevant evidence is international criminal prosecution and investigation of them. Fight against impunity for perpetrators of human rights violations is one of the most important goals of establishing this Court. The regulations underlying the International Criminal Procedure are a strategic combination of the common law, Roman-Germanic law and other major world systems, and consider most advanced rights for the protection of victims of international tribunal. Thus, Statute of the Court predicts a place not only for victims in the preliminary investigation stage, but also in the process of substantive investigation. Article 68 is the main article relevant to the victims whose title is "the protection of victims and witnesses and their participation in the proceedings", which is a real opening for the entrance of victims into the proceedings. Therefore, whenever personal interests are taken into account, the court allows them to present their concerns and attitudes at any trial stage that the court deems 
appropriate, and in a manner not harmful and consistent with the right to defend and requirements of a fair and impartial trial (Saber, 2009, p. 170).

The authorities that have the right to refer to a situation based on the relevant jurisdiction in the Statute of the Court's jurisdiction in accordance with Articles 12, 14, 15 and repeated 15 are as follows:

1- Referral of a case by one of the member states; in accordance with Article 14 of the Statute of the Court, each member can alone refer a case to the court (as defined in the Statute of the Court for a crime committed), provided that the offense has been committed within the territory of one member state or is committed by nationals of one of the member states or by the nationals of a non-member state. In this case, although the relevant guilty government is not a member of the Court, the issue can be raised at the request of a member state (whether the state where a crime is committed, and other member states) in the Court. One can also consider the state under which the crime was committed by nationals of a member state and the territory of a non-member state. In this case, the mere request of any of the member states is subject to the jurisdiction of the Court. In addition, if the offence was committed by nationals of one of member states on the territory of the same country or other member countries.

2- Referal of a case by the Prosecutor; in accordance with Article 15 of the Statute of the Court, the Attorney General can also individually and directly, without the involvement of member states, refer the matter to the Court.

3- The referral of a case by a non-member state; in accordance with paragraph 3 of Article 12, any non-member state or nationals of the country where the crime was committed in its territory, under the Statute of the Court, can deposit a declaration by the Presidential Secretariat, and then accept the exercise of the Court's jurisdiction to that crime. Obviously the exercise of jurisdiction by the Court in this case is one of two principles of territorial or personal jurisdiction (based on the nationality of the perpetrator) (Mir Mohammad Sadeghi, 2008, p. 82).

4- Referral of a case by the UN Security Council; in accordance with the repeated first and second Article 15 of the Statute, it shall be expressed that, under certain situations, regardless of the place of the offense committed or nationality of the offender, pursuant to the Statute of the Court, the Security Council can refer a subject to the Court, and request the court to investigate it. Apparently, the nature and basis of the Court's jurisdiction in this case is the principle of universal jurisdiction, which the Security Council (in line with Chapter VII of the Charter and to maintain international peace and security) has assigned the International Criminal Court as the main responsible body in this regard.

It is worth noting that the Statute of the Court plays a prominent role for victims, and has specified special regulations and advanced measures to protect their rights and compensate damages. This Statute has considered a unique statute in connection with the impanation of justice for the victims, and the commitment and attention of the Rome Statute and International Criminal Court Procedure toward victims are obvious. The history of international criminal prosecutions suggests that, concerning international criminal cases, a special mechanism is intended to enable the Court to avoid the domination of major powers. However, in the area of the proceedings on the regulations relevant to the Court, despite the fact that victims can participate in all stages of the proceedings and present their views directly to the Court, the victim does not play a direct role in the initiation of a criminal proceeding ${ }^{3}$. Yet, they are given the opportunity to present their comments on the decisions issued by the court prosecutor (Saber, 2009, p. 186). Thus, the victims of international crimes have not the right to dispute on the Court's jurisdiction, and this is a big mistake, because mere punishment of criminals is not sufficient, and justice is implemented only when the victims feel criminals have been punished properly, and the Court shall recognize the rights and needs of victims (McKay, 2001, p. 471).

In line with befitting from the advocacy provided by the rule of law, whenever a person undergoes damage caused by violation of the law, he/she can have access to appropriate judicial remedies. Article 75 of the Rome Statute provides reparations for compensating the damages inflicted on victims: "Concerning victim compensation or victim's connection with general rules, including restitution, compensation, and restore the situation to the former state, the Court specifies some regulations. Accordingly, based on the beneficiary's

\footnotetext{
${ }^{3}$ See Article 13 of Statue of International Penal Court. The Article enumerates the authorities that can demand litigation:

A) A situation in which one or some of such crimes have been committed. Based on Article 14, when the case is referred to the court prosecutor through a member state.

B) The situation in which one or some instances of such crimes are committed, and they are referred to the court prosecutor by the Security Council in terms of application of Chapter 7 of the UN Charter.

C) Based on Article 15, the prosecutor has started litigation on such crime.
} 
request or under certain conditions, the Court specifies the extent of any damage, breach of law, or the damages to the victims or in relation with them and implements pertinent general principles...".

Then, in the International Criminal Court, in line with the protection of victims, the right to seek compensation directly from the offender is demanded by the victim for the first time in the history of international criminal justice. Establishment of the International Criminal Court is a milestone in terms of highlighting the role of victims, and the provisions of the Rome Statute have created a new situation in relation to the role of individuals, especially victims and witnesses in international criminal law. For the first time in the history of international criminal justice, the victims can participate in the proceedings, and in addition to the benefit of legal representation and counsel in all proceedings, they can compensate the losses, and also the establishment of credit fund for victims is one of the main achievements of this international document (Daihim, 2001, p. 462).

\section{Conclusion}

Since World War II and in recent years we have witnessed the formation of a variety of special and eclectic international courts whose goal is to punish violators of international humanitarian law, and these transformations are symbolized by the formation of the International Criminal Court. Although such transformations have been so much effective and necessary in terminating the impunity, victims have not achieved pivotal roles in none of them. Two fundamental elements that were examined in the current article include victims' rights in the proceedings of international tribunals, and then the possible compensation of rights of victims in such crimes. Respect and recognize the rights of victims of international crimes since the formation of the International Criminal Court has undergone a developing process and a growing interest in line with the restitution of the rights of victims and compensation for the injuries and losses inflicted in connection with international crimes. The mere punishment of criminals would not heal the victims' spirit, and if victims do not feel that their rights have not been recognized and restituted, there would not be any justice. Therefore, to implement justice, the international Criminal Court sought to play a more effective role in the process of investigation, prosecution and trial for victims. Of course, the Court announced that victims' participation is under proper discretion of the Court, and did expressly reject the possibility to file an action by an individual in international criminal court, even though attaching importance to proceedings and access to the Judiciary and provide justice for the crime's victims is the most important means for authenticating the proceedings in support of the rights of the victim.

As it was indicated in analyzing the judicial history of international courts, international criminal tribunals assign a very limited role to the victims, and they have only the right to participate and attend the proceedings, and only in the International Criminal Tribunal for Lebanon, right of recourse to the court for individuals is explicitly stated. In the meantime, the establishment of the International Criminal Court in order to highlight the role of individuals and victims is considered a turning point, and the provisions of the Rome Statute have specified a new situation in relation to the role of individuals, especially victims and witnesses in international criminal law. For the first time in the history of international criminal justice, the victims can participate in the proceedings, and in addition to benefitting from legal representation and counsel in all proceedings, they can compensate the losses, and also the establishment of credit fund for victims is one of the main achievements of this international fund. This is because the most important goal of the Court is to fight against impunity for international crimes, and the main priority is to maintain international peace and security, and victims' rights are at the next degrees of significance. Some attempts have also been made to guarantee and promote human right achievements in the field of criminal justice, which led to the right of access to justice in the international criminal justice system. Notably, the right of access of victims to justice in order to protect them is one of the effective strategies on the path of implementing justice toward the victims of international crimes.

The provisions of the International Criminal Court in connection with the protection, participation and compensation rights for victims are major developments for international criminal law. Among the International Criminal Courts, it can be said that only the International Criminal Court and Cambodian branches have considered broad regulations for the rights of victims of international crimes, and through a local investigation of the International Criminal Court, it can be said that although this court puts emphasis on international criminal policy and provides the victims with an important place in the criminal justice process, the victim cannot file an action and refer the case to the Court personally or through representation (power of attorney) as the aggrieved member of the international community because of his violated rights. And this is a great vacuum because many of the crimes against humanity, not only have compensatory material or spiritual losses (e.g. forced pregnancy or forced sterilization crimes) and can affect both government and community. Under this condition, create a right to complain or right to individual access to an independent international authority through the pertinent government sometimes can contribute to the emotional healing of the victims. However, these provisions, 
generally in relation to the rights of victims, are inadequate and improper, such that the Court also does not recognize the absolute right of access to court and in some cases imposes some restrictions on this right.

As in countries' civil rights, the main objective underlying lawsuit is to defend the general interests of society and also protect the victim's interests, these rights should be taken into account in the international system as well, whether the individual is natural or legal. Thus, in addition to the states, the individual is also a subject of international law, and a distinct place should be considered for him as well. In the meantime, the Declaration of Basic Principles of Justice for Victims of Crime (1985) and the Basic Principles and Guidelines on the Right to Compensation and Restoration (2006) as two normative documents on the policies of the United Nations can be regarded as the international bills of victims' rights, thus the victim as one of the main actors of crime gradually entered the criminal justice process. The basic principle declarations, litigation guidelines, and the guidelines to right to a remedy and reparation for victims of serious violations of international human rights and grave breaches of international humanitarian law 2005 and 2006 all revolve around the single subject of the victims and their right to order compensation of damages incurred on them. and according to paragraph 2 of Article 33 of international responsibility proposal: neither of the articles in the proposal does not cause damage to any right emanated from international liability of the governments that may belong to any person or entity other than the government". The document indicates that although liability dominates the relationship between government and government, this proposal negates the possibility of existence of such relationship between government and individuals. These documents, which are mainly non-binding mainly emphasize the right to petition the governments due to the violations of international humanitarian law.

While significant steps have been taken in connection with the rights of victims and compensation for the damage they have suffered as a result of the commission of international crimes under international criminal law provisions, the most important right of victims to access to international authorities to refer directly to damaging situation have still been ignored, and this is a major gap in the international criminal process.

\section{References}

Aqaei JanatMakan, H. (2009). The Special Tribunal for Lebanon, a different look at international criminal law; Law Quarterly. Journal of Law and Political Science, 39(2).

Daihim, A. R. (2001). An Introduction to International Criminal Law in the light of the Statute of the International Criminal Court. Publications Center of the Ministry of Foreign Affairs.

Foroughi, F. A. (2004). Forgivable offenses in Iran. Shiraz University Journal of Humanities and Social Sciences, 21(2).

Kapitan, H., \& Malj, M. (2005). Restorative justice in the documents of the United Nations, crime, victims, justice, translated by Amir Samavati Pirouz; Khalilian Publications, Tehran.

McKay, F. (2001). on behalf of The Victims Rights Working Group, ext: The International Criminal Court: Edited by, Roys, lee.

Mir Mohammad Sadeghi, H. (2008). International Criminal Court (3rd ed.). Tehran; Dadgostar Publications.

Musila, G. (2009). Options for transitional justice in Kenya: autonomy and the challenge of external prescriptions. Int J Trans Justice. https://doi.org/10.1093/ijtj/ijp018

Omidi, J. (2003). criminal proceeding and human rights. Parliamentary and Research, (38).

PourOstad, M. (2006). Principles and rules of transnational procedure (translation) (1st ed.). Shahr Danesh Publications.

Pradle, J. (1991). History of Penal Thoughts, translated by Najafi Abrand Abadi; Shahid Beheshty University'.

Raijian Asli, M. (2001). Victims and the criminal justice system. Journal of Judiciary Law, (52-53).

Raijian Asli, M. (2002). The victim in the criminal process (1st ed.). Tehran; Khate-e-Sevom Publications.

Raijian Asli, M. (2005). Development of universal rights and victims on the basis of the principle of alignment between victim rights and offender in the context of a fair hearing. Journal of Judiciary Law, (56-57).

Saber, M. (2009). Legal procedures in international criminal courts. Quarterly of Law, (2).

Shams, A. (2004). Code of Civil Procedure (Vol. 2, 6th ed.). Derak Publications.

Tavajohi, A. A. (2002). The significance of protection of victims of international documents and conventions. Journal of Qom Complex Higher Education, (9).

Zakerian, M. (2002). Human Rights in the new millennium. University of Tehran Publications. 
Zakerian, M. (2013). Agha Alikhani, M. International Criminal Tribunal for the former Yugoslavia, activities and achievements. Quarterly of Foreign Policy, 6(1).

\section{Copyrights}

Copyright for this article is retained by the author(s), with first publication rights granted to the journal.

This is an open-access article distributed under the terms and conditions of the Creative Commons Attribution license (http://creativecommons.org/licenses/by/4.0/). 